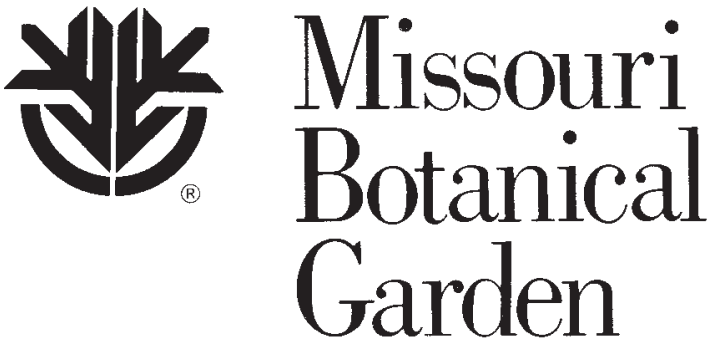

Two New Species of Cyperus (Cyperaceae) from the Zambezian Region of Africa

Kenneth Bauters, Marc Reynders, Isabel Larridon, *

Wim Huygh, and Paul Goetghebeur

Ghent University, Department of Biology, Research Group Spermatophytes,

K. L. Ledeganckstraat 35, 9000 Gent, Belgium. *Author for correspondence: isabel.larridon@ugent.be
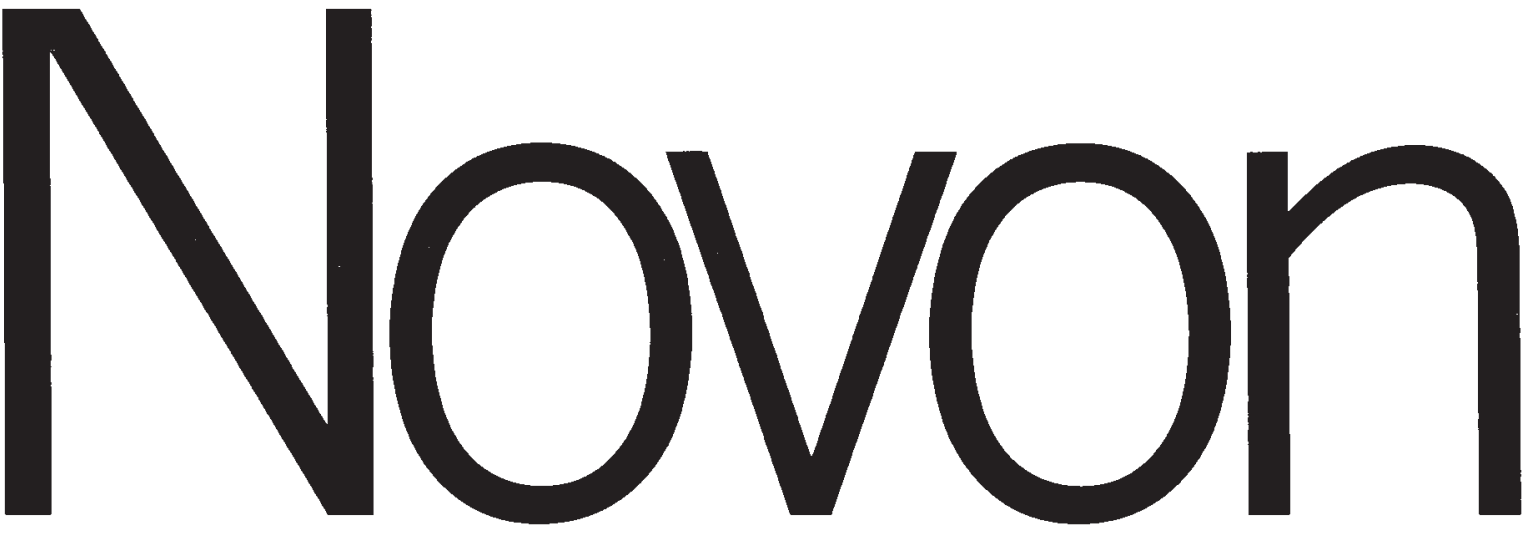

A Journal for Botanical Nomenclature 



\title{
Two New Species of Cyperus (Cyperaceae) from the Zambezian Region of Africa
}

\author{
Kenneth Bauters, Marc Reynders, Isabel Larridon,* \\ Wim Huygh, and Paul Goetghebeur
}

Ghent University, Department of Biology, Research Group Spermatophytes, K. L. Ledeganckstraat 35, 9000 Gent, Belgium. *Author for correspondence: isabel.larridon@ugent.be

Abstract. Cyperus absconditicoronatus Bauters, Reynders \& Goetgh. and C. unispicatus Bauters, Reynders \& Goetgh., two new species of Cyperus L. (Cyperaceae) from Angola and Zambia, are recognized. Cyperus absconditicoronatus is a tall species $(55-100 \mathrm{~cm})$ characterized by a scaled rhizome, a single terminal capitulum, a ciliated spikelet bract, and deciduous spikelets. Cyperus unispicatus can be recognized by a swollen and fibrous stem base growing from slender rhizomes, a single terminal spike, and short involucral bracts. The taxa are described and illustrated, and differences with the closest resembling species are discussed.

Key words: Africa, Angola, Cyperaceae, Cyperus, IUCN Red List, Zambia.

The genus Cyperus L. s. str. (Cyperaceae) includes 696 accepted species worldwide (Govaerts et al., 2008). Cyperus can be recognized by a usually anthelate inflorescence often with conspicuous involucral bracts, spikelets with several to many fertile and usually distichous glumes, the rachilla of the spikelet either persistent or not, the flowers without a perianth, and a trifid, less often bifid, or rarely nondivided style.

During the examination of some specimens of Cyperus in the Ghent University Herbarium (GENT) as part of ongoing research on the genus by the authors, several specimens were encountered that could not be assigned to any known species in the genus (after identification with Kükenthal, 19351936; Chermezon, 1937; Hooper \& Napper, 1972; Haines \& Lye, 1983). One of the specimens (H. \& E. Hess 52/545) was incorrectly identified by Mincier (1984) as Mariscus albopilosus C. B. Clarke (accepted name = Cyperus albopilosus (C. B. Clarke) Kük.). In his master's thesis on the Cyperaceae from Angola, he mentioned another specimen (H. \& E. Hess 52/262) as "Mariscus sp. nov." (Mincier, 1984: 180). Both specimens clearly belong to the same new species. In the herbarium of the National Botanic Garden of Belgium (BR), a third specimen (M. G. Bingham
7042/2) of this taxon was found, incorrectly identified as $C$. rhynchosporoides Kük.

Mincier (1984: 182) also mentioned the only known specimen (H. \& E. Hess 52/34) of the second new species, Cyperus unispicatus Bauters, Reynders \& Goetgh., as "Mariscus sp. nov." He placed this new species in Cyperus sect. Bulbocaules (C. B. Clarke) Kük., which is characterized by a swollen stem base.

1. Cyperus absconditicoronatus Bauters, Reynders \& Goetgh., sp. nov. TYPE: Angola. Bié: Falls of Cutato River, S of [Kuvango]-Cuchi Rd., 15 Sep. 1952, H. \& E. Hess 52/262 (holotype, GENT). Figures 1, 2A, B.

Haec species Cypero rhynchosporoidi Kük. et C. albopiloso (C. B. Clarke) Kük. similis, sed a hoc bracteis involucralibus 3 , inflorescentia majore atque nucula oblonga, ab illo habitu robustiore atque culmo ad basim non incrassato distinguitur.

Perennial herb; rhizomes 6-9 $\mathrm{mm}$ thick, with conspicuous red-brown scales that split crown-like as the rhizome thickens; culms $55-100 \times$ ca. $0.2 \mathrm{~cm}$, slender, triangular, erect, ciliated with hairs on the ribs, scabrous, stem base not swollen. Leaves 5 to 8 , all basal, lowest leaves reduced to their sheath; sheaths to $13 \mathrm{~cm}$, cinnamon colored; highest leaves with blades; blades rough, 35-65 × 0.5-0.7 cm. Inflorescence a single, terminal, spherical head, 1.5$1.6 \mathrm{~cm}$ diam.; involucral bracts 3 , ciliated on the edges, $2.5-9.5 \times 0.3-0.4 \mathrm{~cm}$. Spikelets deciduous, 5$8 \times 1-1.2 \mathrm{~mm}$; spikelet bract $2-3 \times$ ca. $1 \mathrm{~mm}$ (measured on folded bract), ciliated on the midrib; spikelet prophyll $2-3 \times$ ca. $1 \mathrm{~mm}$ (measured on folded prophyll); glumes 2 per spikelet, distichous; first glume completely enveloping nutlet, $5-8 \mathrm{~mm}$ long, 12-veined; second glume strongly reduced, 3.5$4 \times$ ca. $0.8 \mathrm{~mm}$, midrib white. Flowers 1 per spikelet, bisexual; stamens 3 , anthers ca. $7 \mathrm{~mm}$; style $1-2 \mathrm{~mm}$; stigma branches 3 . Nutlet $5-6 \times$ ca. $1 \mathrm{~mm}$, oblong, trigonous, apiculate, black. 


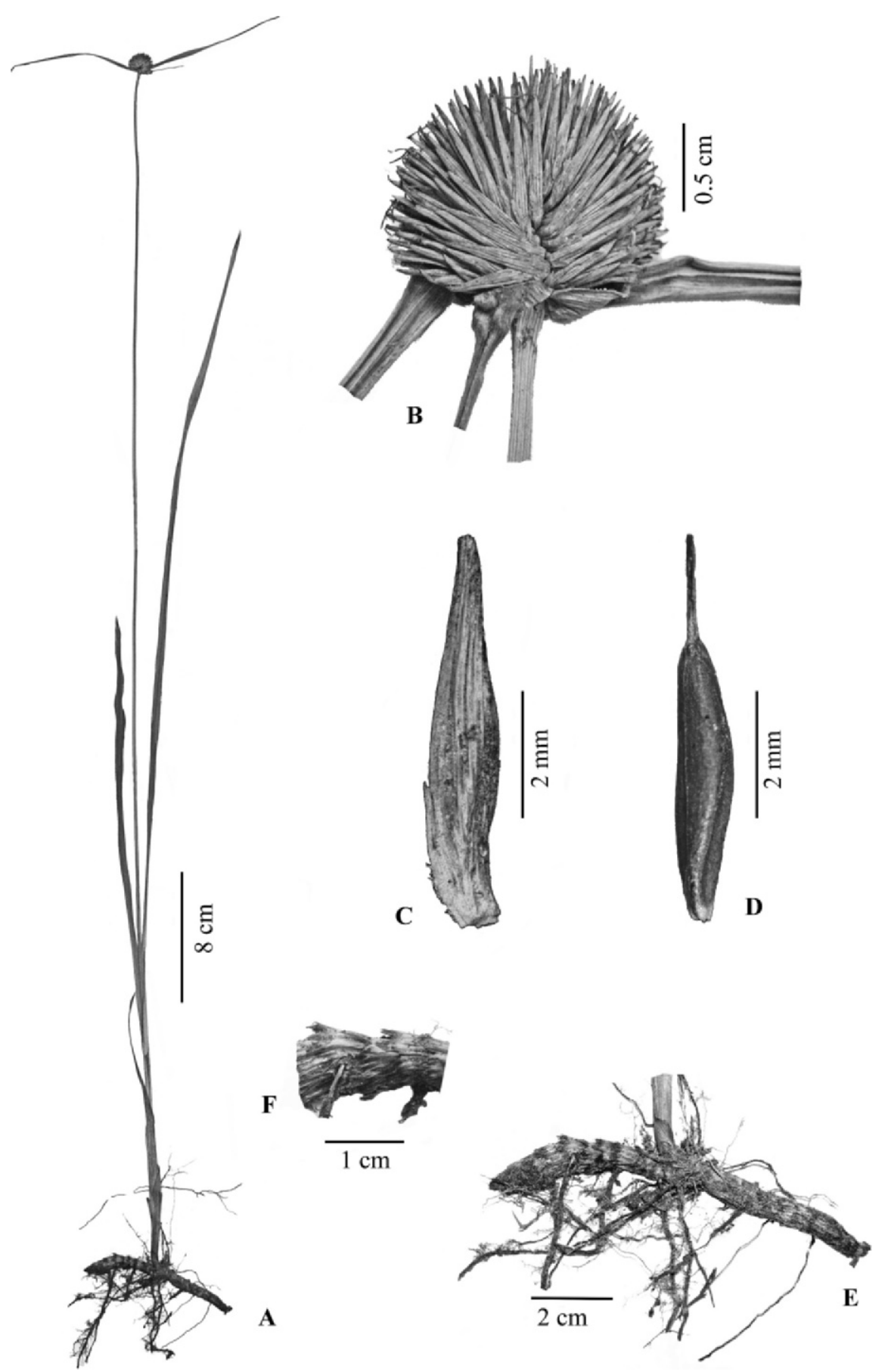

Figure 1. Cyperus absconditicoronatus Bauters, Reynders \& Goetgh. - A. Habit. —B. Inflorescence. —C. Spikelet. —D. Nutlet. —E. Rhizome. —F. Detail of rhizome scales. From the holotype H. \& E. Hess 52/262 (GENT).

IUCN Red List category. Cyperus absconditicoronatus should be classified as Data Deficient (DD) according to IUCN Red List criteria (IUCN, 2001).
Etymology. The epithet of Cyperus absconditicoronatus means "with hidden crown" and refers to the scales of the rhizome, which split crown-like. 
Table 1. Morphological comparison of Cyperus absconditicoronatus, C. rhynchosporoides, C. unispicatus, and C. stramineoferrugineus.

\begin{tabular}{|c|c|c|c|c|}
\hline & C. absconditicoronatus & C. rhynchosporoides & C. unispicatus & C. stramineoferrugineus \\
\hline Basal parts & rhizomes, 6-9 $\mathrm{mm}$ thick & rhizomes, $3 \mathrm{~mm}$ thick & slender rhizome & caespitose \\
\hline Culm base & not swollen & slightly swollen & swollen: $0.5-0.9 \mathrm{~cm}$ & swollen: $0.9-1.3 \mathrm{~cm}$ \\
\hline $\begin{array}{l}\text { Culms, dimensions } \\
\qquad(\mathrm{cm})\end{array}$ & $55-100 \times$ ca. 0.2 & $10-50 \times 0.1-0.2$ & $(9-) 20-32 \times 0.05-0.1$ & $10-15 \times 0.05-0.1$ \\
\hline Culms, section & triangular & triangular to rounded & triangular & $\begin{array}{l}\text { triangular, slightly } \\
\text { compressed }\end{array}$ \\
\hline $\begin{array}{l}\text { Leaf blade, } \\
\quad \text { dimensions }(\mathrm{cm})\end{array}$ & $35-65 \times 0.5-0.7$ & ca. $30 \times 0.3-0.5$ & $(2-) 5-14 \times 0.1-0.2$ & $5-15 \times 0.03-0.1$ \\
\hline Inflorescence & spherical capitulum & spherical capitulum & ovate capitulum & spherical capitulum \\
\hline $\begin{array}{l}\text { Capitulum, } \\
\text { diam. }(\mathrm{cm})\end{array}$ & $1.5-1.6$ & ca. 1 & $0.4-0.7$ & $0.6-1$ \\
\hline Involucral bracts & 3 & 2 to 4 & 1 to 2 & 2 to 3 \\
\hline $\begin{array}{l}\text { Involucral bracts, } \\
\text { length }(\mathrm{cm})\end{array}$ & $2.5-9.5$ & $3-6$ & $0.7-1.6$ & $3-5$ \\
\hline Spikelets & 2 glumes, 1 flower & 2 glumes, 2 flowers & 3 flowers & 4 to 5 flowers \\
\hline $\begin{array}{l}\text { Spikelets, } \\
\quad \text { dimensions (mm) }\end{array}$ & $5-8 \times 1-1.2$ & $5-6 \times$ ca. 1 & $2-3.6 \times$ ca. 1 & $3-5 \times$ ca. 2 \\
\hline Glumes, length (mm) & $5-8$ & $4.5-5$ & $1.5-2.5$ & $3.5-4$ \\
\hline Spikelet bracts & ciliated on midrib & not ciliated on midrib & not ciliated on midrib & NA \\
\hline $\begin{array}{l}\text { Nutlet, dimensions } \\
\quad(\mathrm{mm})\end{array}$ & $5-6 \times$ ca. 1 & NA & $1.1-1.3 \times 0.5-0.8$ & $1.5-1.8 \times 1-1.2$ \\
\hline Distribution & Angola, Zambia & Angola, Zambia, Congo & Angola & Tanzania \\
\hline
\end{tabular}

NA, data not available.

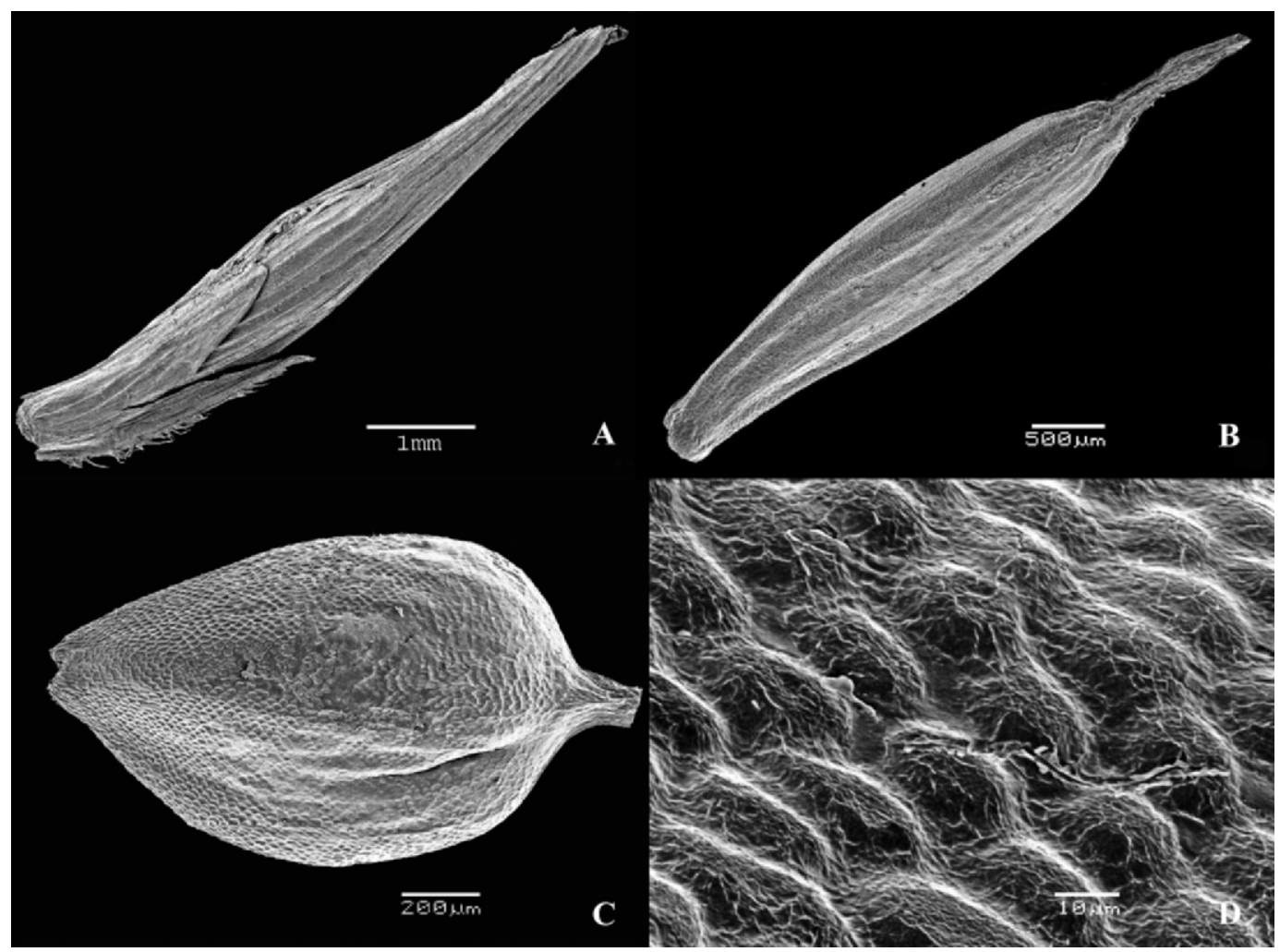

Figure 2. A, B. SEM micrographs of Cyperus absconditicoronatus Bauters, Reynders \& Goetgh. - A. Spikelet. —B. Nutlet. C, D. SEM micrographs of C. unispicatus Bauters, Reynders \& Goetgh. - C. Nutlet. —D. Nutlet epidermal cells. 


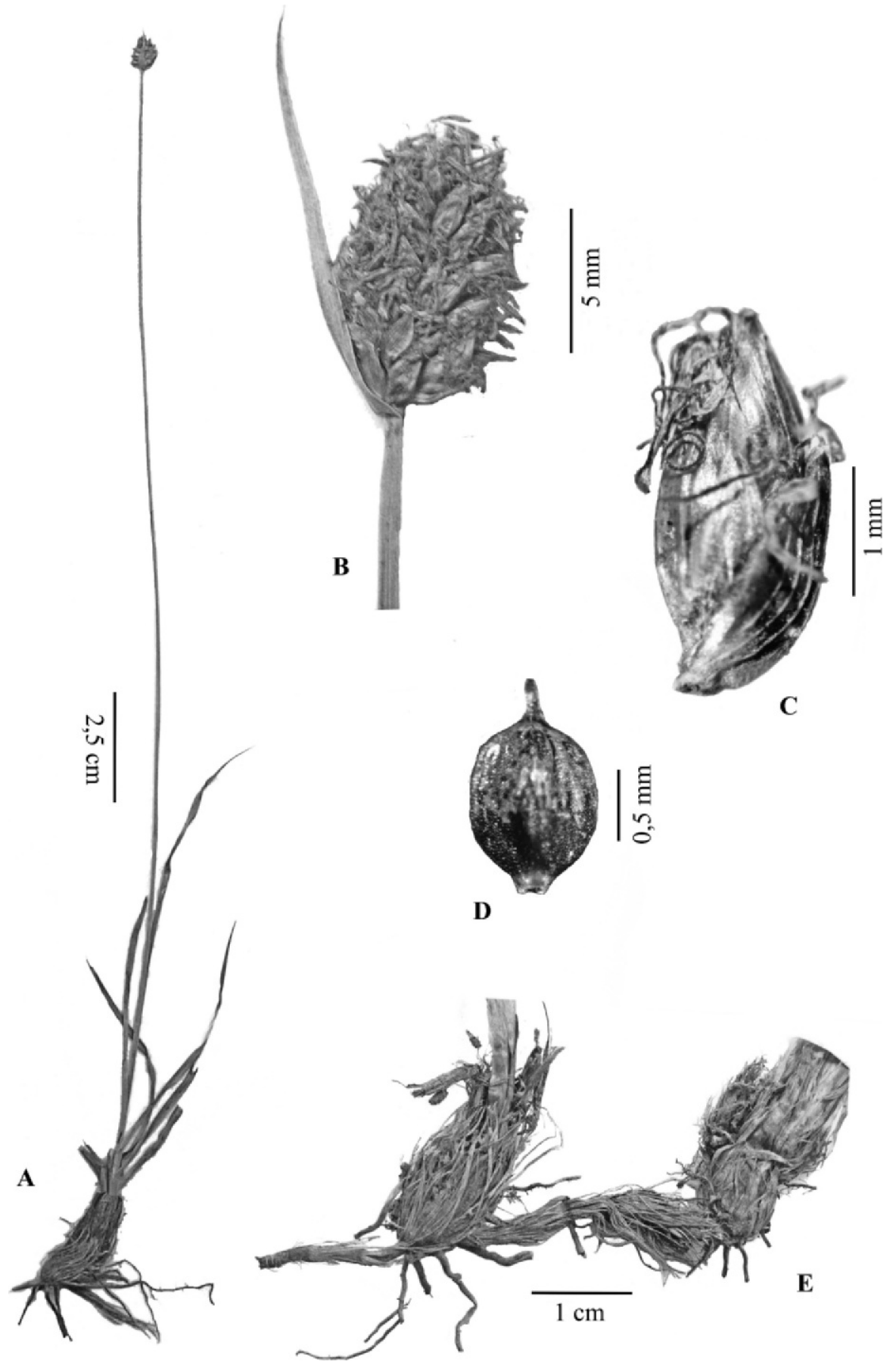

Figure 3. Cyperus unispicatus Bauters, Reynders \& Goetgh. - A. Habit. -B. Inflorescence. —C. Spikelet. —D. Nutlet. -E. Plant bases. From the holotype H. \& E. Hess 52/34 (GENT).

Relationships. Cyperus absconditicoronatus is a tall species characterized by a distinctly scaled rhizome, deciduous spikelets, and a ciliated spikelet bract. The closest resemblance was found in the species C. rhynchosporoides, the type of Cyperus sect. Ochrocephali Kük. (Kükenthal, 1935-1936). However, $C$. rhynchosporoides is much smaller in all aspects and has a slightly swollen stem base (Table 1). As 
mentioned, Mincier (1984) identified one of the specimens of C. absconditicoronatus as C. albopilosus. However, C. albopilosus has a much smaller capitate inflorescence, an ovate nutlet, and only two involucral bracts.

Paratypes. ANGOLA. Bié: Baixo [Kuvango], $30 \mathrm{~km} \mathrm{~N}$ of Caiundo, $\mathrm{N}$ of Mission Capico, $1200 \mathrm{~m}, 31$ Jan. 1952, H. \& E. Hess 52/545 (GENT). ZAMBIA. North-Western Province: Mwinilunga Distr., Wanyizenzi, 7 Jan. 1991, M. G. Bingham 7042/2 (BR).

2. Cyperus unispicatus Bauters, Reynders \& Goetgh., sp. nov. TYPE: Angola. Huíla: near Mupa Catholic Mission in Cuanhama, 228 km $\mathrm{S}$ of [Kuvango], $1250 \mathrm{~m}, 9$ Sep. 1952, H. \& E. Hess 52/34 (holotype, GENT). Figures 2C, $\mathrm{D}, 3$.

Haec species Cypero stramineoferrugineo Kük. similis, sed ab eo culmo altiore, inflorescentia densiore atque spiculis 3floris distinguitur.

Perennial herb, forming slender rhizomes; rhizomes dark brown, 15-30 × 1-1.5 mm; stem base swollen, 5-9 mm wide, covered in fibrous remains of old leaf sheaths; culms (9-)20-32 × 0.05-0.1 cm, slender, triangular, glabrous. Leaves 5 to 9 , all basal, sheaths up to $4 \mathrm{~cm}$ long, blades (2-)5-14 $\times$ $0.1-0.2 \mathrm{~cm}$, ciliated on the edges and midrib. Inflorescence a single terminal capitate spike, slightly pseudolateral by its involucral bract; spike ovate, 4-7 × (0.5-)0.9-1 mm; involucral bracts 1 or 2 , largest $0.7-1.6 \times 0.07-0.1 \mathrm{~cm}$, second involucral bract strongly reduced. Spikelets deciduous but bract and prophyll persistent, 2-3.6 $\times$ ca. $1 \mathrm{~mm}$; glumes $1.5-2.5 \times$ ca. $1 \mathrm{~mm}$, distichous. Flowers 3 per spikelet; stamens 3 ; style branches 3 . Nutlet obovate, $1.1-1.3 \times 0.5-0.8 \mathrm{~mm}$, triangular, apiculate.

IUCN Red List category. Cyperus unispicatus should be classified as Data Deficient (DD) according to IUCN Red List criteria (IUCN, 2001).

Etymology. The epithet of Cyperus unispicatus means "with one spike" and refers to the single terminal spike.

Relationships. Cyperus unispicatus is characterized by a swollen stem base on a slender rhizome and a single terminal spike with short involucral bracts. Cyperus unispicatus most closely resembles C. stramineoferrugineus Kük. (Kükenthal, 1935-1936; Haines \& Lye, 1983). However, the latter species has a less dense, capitate inflorescence, a shorter culm, and spikelets with four to five flowers (Table 1).
Based on its morphology, C. unispicatus could be classified in Cyperus sect. Bulbocaules subsect. Kyllingiformes Kük. This group consists of perennial herbs with triangular, glabrous (seldom hairy) culms. The stem base is swollen and covered with the sometimes fibrous remains of old leaf sheaths. Most species have thick rhizomes, although some have stolons (C. chevalieri Kük.). The inflorescence always consists of a dense spherical or irregular capitulum. The deciduous spikelets are elliptical to lanceolate with one to six flowers.

Discussion. Cyperus absconditicoronatus and C. unispicatus are both found in miombo woodlands in the Zambezian region of Africa. Although only known from a few localities, the new species are potentially present throughout this still poorly known ecoregion, which ranges from Angola to the shores of Lake Victoria in Tanzania.

Both species are characterized by deciduous spikelets and a head-like contracted inflorescence. In addition, Cyperus absconditicoronatus has spikelets on which only one nutlet matures. This combination of characters can be found in various lineages within Cyperus (especially in the chlorocyperoid clade) such as Cyperus sect. Bulbocaules, Cyperus sect. Ochrocephali, Kyllinga Rottb., Lipocarpha R. Br., and Ascolepis Nees ex Steud. Homologies of the inflorescences of these taxa are still unclear due to the unresolved phylogeny of the Cyperus clade with chlorocyperoid anatomy to which these species belong. It is thus premature to place the two new species in any of the known subdivisions, and further study with additional molecular markers is needed to reveal the exact position of the new species. Nevertheless, the two new species can be easily distinguished from all other Cyperus species based on morphological evidence.

Acknowledgments. We particularly thank Jan Rammeloo, the director of the National Botanic Garden of Belgium, for the use of the SEM, as well as Frank Van Caeckenberghe for his expertise in taking the SEM micrographs. We thank the curator of $\mathrm{BR}$ for the loan of material.

\section{Literature Cited}

Chermezon, H. 1937. Cypéracées in H. Humbert (editor), Flore de Madagascar, 29 $\mathrm{fam}$. Imprimerie Officielle, Tananarive.

Govaerts, R., D. A. Simpson, P. Goetghebeur, K. L. Wilson, T. Egorova \& J. Bruhl. 2008. World Checklist of Cyperaceae. The Board of Trustees of the Royal Botanic Gardens, Kew. Published on the Internet; <http://www. kew.org/wcsp/monocots/>, accessed 16 June 2008.

Haines, R. W. \& K. A. Lye. 1983. The Sedges and Rushes of East Africa. East African Natural History Society, Nairobi. 
Hooper, S. S. \& D. M. Napper. 1972. Cyperaceae. Pp 278-349 in F. N. Hepper (editor), Flora of West Tropical Africa, Vol. 3. Crown Agents for Overseas Governments and Administration, London.

IUCN. 2001. IUCN Red List Categories and Criteria, Version 3.1. Prepared by the IUCN Species Survival Commission. IUCN, Gland, Switzerland, and Cambridge, United Kingdom.
Kükenthal, G. 1935-1936. Cyperaceae-ScirpoideaeCypereae in A. Engler (editor), Das Pflanzenreich, Regni Vegetabili Conspectus 4(20). H. R. Engelmann, Stuttgart.

Mincier, A. 1984. Bijdrage tot de kennis van de Cyperaceae van Angola. Master's Thesis, Ghent University, Ghent, Belgium. 